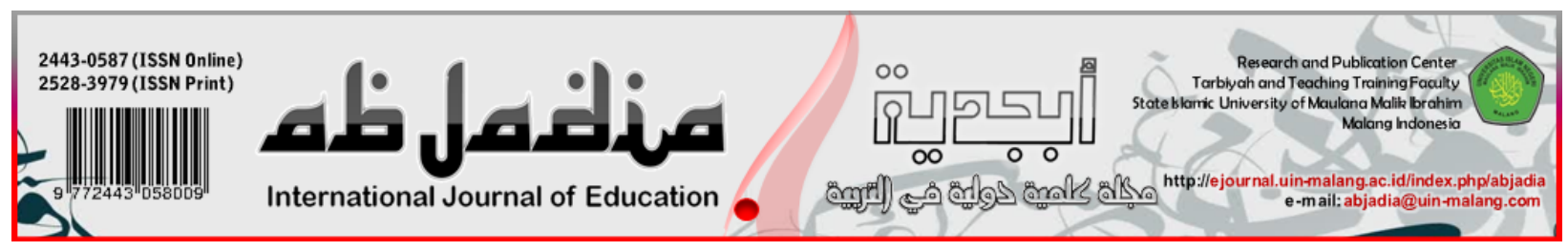

\title{
EXPERIENCED TEACHERS' PERCEPTIONS: MATH-FOCUSED STEAM LEARNING
}

\author{
Dewi Rosikhoh', Liny Mardhiyatirrahmah ${ }^{2}$, Abdussakir ${ }^{3}$, Ahmad Abtokhi', Imam Rofiki ${ }^{5}$ \\ 1,2,3,4,5 Universitas Islam Negeri Maulana Malik Ibrahim Malang, Indonesia
}

\section{Article History: \\ Received : 2019-11-29 \\ Revised : 2019-12-27 \\ Accepted : 2019-12-28 \\ Published : 2019-12-30}

\section{Keywords:}

Experienced Teachers, STEAM,

Mathematics Learning

Correspondence Address: dewirosikhoh@gmail.com

linymardhiyatirrahmah@gmail.com

sakir@mat.uin-malang.ac.id

abtokhiuin@gmail.com

imam.rofiki@uin-malang.ac.id

\begin{abstract}
Science, technology, engineering, arts, and mathematics (STEAM) have been applied in various countries because they have been able to answer the challenges of the globalization era. The implementation of STEAM at school has demanded that teachers have a role in making a relationship between disciplines in science contained in STEAM. The purpose of this research was to describe the perceptions of experienced teachers about math-focused STEAM learning. The research was a descriptive study on 14 vocational high school mathematics teachers in Malang, Indonesia. They had 20-30 years of teaching experience. Data were collected using essay questionnaires. The result showed that their perceptions of STEAM learning were positive. However, they also said that there were several obstacles to math-focused STEAM learning. The first obstacle was the unavailability of supporting literature. The second obstacle was that there were teachers who have no received training. The third obstacle was only a limited number of mathematics material that can be applied in STEAM learning. Additionally, the teacher stated that mathematics was more suitable as supporting contain in STEAM learning than as the primary focus.
\end{abstract}

\section{(C) Introduction}

The rapid development of science and technology is inevitable but the expansion must be faced and mastered (Kim, 2017). Problems in the current era of globalization are complex with various aspects. The problems are not enough to be solved by one discipline only, but solving the problem requires convergence from several disciplines and creative problem solving abilities (Kim \& Kim, 2016). STEAMbased learning (Science, Technology, Engineering, Art, and Mathematics) can help students to stimulate the ability of the thinking process and facing the challenges of the globalization era (Henriksen, 2017; Sheffield, Koul, Blackley, Fitriani, Rahmawati, \& Resek, 2018). STEAM learning is now a concern of world education (Kang, 2019; Sheffield et al., 2018).

STEAM is a meta discipline that integrates science, technology, engineering, art and mathematics into an integrated approach that can be implemented in schools (Herro \& Quigley, 2017). Changing the curriculum in Indonesia to the 2013 curriculum 
indicate an improvement in education by the government. The 2013 curriculum which integrates thematic learning is very suitable to be integrated with STEAM-based learning. Elementary schools and junior high schools are the levels of education units suitable for the application of STEAM-based learning (Herro, Quigley, Andrews, \& Delacruz, 2017). This is because at this level each subject is taught thematically integrated. Likewise, the implementation of STEAM can be done at the high school level, including science, technology, art, and mathematics subjects. Each subject at the high school level has a clear concentration, science and social science are no longer integrated subjects, but the subjects are divided into the concentration of their respective discipline.

STEAM as a learning approach at the high school and vocational levels can be implemented in subjects that have a connection with the others discipline of science at STEAM learning, for example, mathematics learning. In learning mathematics, the implementation of STEAM can be done by understanding the relationship between existing mathematical concepts with other scientific disciplines contained in STEAM (Yakman, 2008). The linkages between these concepts can be built through the ability to think critically, creatively and problem solving skills so that it will produce an idea or complex skills to formulate a solution of the problem at hand (Herro \& Quigley, 2016; Jho, Hong, \& Song, 2016). Not only in the context of learning, but the ability to solve problems can also be applied to solve problems in real-life (Gürbüz \& Erdem, 2016). National Council of Teachers of Mathematics recommends 4 principles of mathematics learning, namely mathematics as problem solving, mathematics as reasoning, mathematics as communication, and mathematics as a connection (NCTM, 2000). Mathematics is one of the disciplines of science integrated into STEAM so that the implementation of STEAM in learning mathematics only applies the ideas of other disciplines, namely science, technology, engineering, and art. STEAM implementation in mathematics learning can be done well when the teacher as a learning companion has understood the meaning of an implementation (Herro \& Quigley, 2017; Jho et al., 2016; Kim \& Lee, 2018).

The role and quality of teachers is a very important factor in increasing talented leaders in the future (Tehseen \& Hadi, 2015). The effectiveness of teaching competence is very important as a requirement in education. Teacher professionalism is demanded to continue to develop by the times, the development of science and technology, and the needs of the community (Timperley, 2015). This demand applies to all teachers, both novice and experienced teachers. One of the factors that shows the low quality of education in Indonesia is the weakness of teachers in exploring the potential of students' higher-order thinking skills such as analytical thinking, critical thinking, creative thinking, or reasoning. Therefore, some studies show the problems that arise from the change and expansion of teaching competency standards that must be possessed by a teacher (Park, Byun, Sim, Han, \& Baek, 2016). The role of the teacher has evolved from teacher-centered teacher to student-centered and the skills needed for 
qualified teachers have also changed (Keiler, 2018). In STEAM-based learning, the teacher will have a challenge about how to encourage students to be able to use their understanding and logic actively, think critically and creatively and use problem solving skills. Teachers are not only as facilitators, but the teachers must also participate in building understanding to make a relationship between disciplines contained in STEAM.

In the STEAM learning process, teachers have many assignments, like to observe the group of study, provide stimulus by giving questions, give opinions and suggestions, and evaluate students' products through project-task. Meanwhile, students that together in a learning group build an understanding of the concepts which were discussed as well as learning how to make integration connections among disciplines in STEAM (Yakman \& Lee, 2012). For example, when students are confronted with the concept of shape and pace, they must be able to develop the concept in other disciplines. The topic of shape and space can be created and designed with different techniques. Each space can also be designed by adding elements of art to each creation, for example adding color to each side of the space. Making and learning to space can be done using the technology of mathematical software, one of which is GeoGebra (Bhagat \& Chang, 2015). Implementation of STEAM in the classroom can produce a product of learning that is complex and perfect in improving the quality of education (Henriksen, 2014). Implementation of STEAM certainly provides its challenges for teachers. The integration of science, technology, engineering, art, and mathematics forces teachers to continue improving their competence (Boy, 2013). Sensitivity to these developments naturally results in different perceptions between young teachers and experienced teachers (Jho et al., 2016; Koni \& Krull, 2018). For example in Korea, experienced teachers have a positive view of STEAM learning ( Kim \& Lee, 2018; Kim \& Lim, 2019; Park et al., 2016). But the research also encountered obstacles in implementing STEAM learning in the classroom such as time, workload, administrative and financial constraints that were less supportive (Park et al., 2016). Another obstacle that focuses on mathematics in primary schools is the lack of time, materials and educational resources (Kim et al., 2019).

The Indonesian government has recently supported STEAM learning at the Vocational High School level. This is indicated by the holding of STEAM training by the government for vocational high school teachers. The target of this training is teachers who can teach one of the subjects integrated into STEAM learning. The research focus on mathematics that has been done is the perception of teachers at the elementary school level. Since mathematics learning in primary schools is different from middle school learning, and the principles of mathematics learning imply that mathematics is an applied science in other disciplines, it is necessary to conduct further research on teacher perceptions that focus on mathematics at the secondary school level. Hence, this study investigates the perception of experienced teachers of STEAM learning that focuses on mathematics. 


\section{[0] Method}

This study used a qualitative approach to the type of descriptive research. The subjects of the study were 14 mathematics teachers of various vocational high school in Malang. The chosen subjects have teaching experience ranging from 20-30 years. In addition, the teacher has a minimum academic qualification of S1 and is over 40 years old. Data collection techniques using essay questionnaires. The questionnaire used was developed from Kim et al. (2019). Teachers' perceptions are based on their responses to the following five items; a) What do you think of 'convergence' (unification of Science, Technology, Engineering, Art, Mathematics) in STEAM learning?, b) How is the application of STEAM learning at the level of Vocational High School after gaining support from the government?, c) What are the easy subjects to be combined with mathematics to apply Math-Focused STEAM learning?, d) What is your view of mathematical material that is suitable to be taught with STEAM learning?, e) How to use the appropriate mathematical material with the STEAM learning?, f) How to teach Mathematics with STEAM learning?, g) If your plan is successful, will you re-apply the method of teaching mathematics with the STEAM learning in the future? The teacher is asked to respond freely by writing an argument based on the experience and knowledge of the teacher in the column provided. Then, the teacher's answers will be analyzed and presented descriptively.

\section{Result}

Tables 1 and 2 present the answers to essay questionnaire filled by 14 mathematics teachers who have teaching experience ranging from 20 - 30 years. Half of the teachers taught in public vocational high schools and the others were in private vocational high schools. There were $50 \%$ of male teachers and the others were female. The chosen subjects contained $40 \%$ that had graduated in the master program and the others had finished undergraduate program. Data were collected after the STEAM training was held by the government at the level of vocational high school. The target of training was teachers who taught one of the subjects contained in STEAM.

Table 1. Teachers' Perceptions and Experiences of Teaching with STEAM learning

\begin{tabular}{|c|c|c|c|c|c|}
\hline Subject & $\begin{array}{l}\text { What do you think of } \\
\text { 'convergence' (unification of } \\
\text { Science, } \\
\text { Engineering, } \\
\text { Mathematics) in ST, STEAM } \\
\text { learning? }\end{array}$ & $\begin{array}{l}\text { How is the application of STEAM } \\
\text { learning at the level of Vocational } \\
\text { High School after gaining support } \\
\text { from the government? }\end{array}$ & $\begin{array}{l}\text { Time of } \\
\text { teaching }\end{array}$ & Gender & School \\
\hline & Answer of Question (Number 1) & Answer of Question (Number 2) & & & \\
\hline 1 & $\begin{array}{l}\text { Strongly agree because they } \\
\text { are interrelated }\end{array}$ & Need to support & 20 years & Male & $\begin{array}{l}\text { SMKN } 2 \\
\text { Singosari }\end{array}$ \\
\hline
\end{tabular}




\begin{tabular}{|c|c|c|c|c|c|}
\hline 2 & $\begin{array}{l}\text { STEAM increases students' } \\
\text { creativity in critical thinking and } \\
\text { can be applied in real-life }\end{array}$ & $\begin{array}{l}\text { Event hough, STEAM is supported by } \\
\text { government, there is still a difficulty } \\
\text { to apply the learning in the } \\
\text { classroom, like no reference about } \\
\text { the approach }\end{array}$ & 20 years & Female & $\begin{array}{l}\text { SMK Asy- } \\
\text { Syafi'iyyah }\end{array}$ \\
\hline 3 & $\begin{array}{l}\text { Good but the possibility of the } \\
\text { teachers are still experiencing } \\
\text { difficulties to convey to } \\
\text { students about science if } \\
\text { teachers are not equipped with } \\
\text { the skills of science }\end{array}$ & Must be implemented & 20 years & Female & $\begin{array}{l}\text { SMKN } 2 \\
\text { Singosari }\end{array}$ \\
\hline 4 & $\begin{array}{l}\text { Good, because with the } \\
\text { collaboration of the children } \\
\text { become more aware that the } \\
\text { material that one with another } \\
\text { mutual regard and usability } \\
\text { learn }\end{array}$ & Need to be practiced & 20 years & Male & SMK Khairuddin \\
\hline 5 & $\begin{array}{l}\text { It can train students to be } \\
\text { creative, cooperative, and can } \\
\text { be applied in real-life so that } \\
\text { learning mathematics is } \\
\text { interesting }\end{array}$ & $\begin{array}{l}\text { If there are supporting items from } \\
\text { the government, especially the } \\
\text { reference to mathematics books that } \\
\text { integrated with learning of STEAM, it } \\
\text { will be effective }\end{array}$ & 20 years & Female & $\begin{array}{c}\text { SMK NU } \\
\text { Gondanglegi }\end{array}$ \\
\hline 6 & $\begin{array}{l}\text { Very necessary at all, such as } \\
\text { the thematic at the school level } \\
\text { of the base }\end{array}$ & $\begin{array}{l}\text { Not optimal yet. } \\
\text { The education and training programs } \\
\text { that have been conducted are not yet } \\
\text { optimal }\end{array}$ & 20 years & Male & $\begin{array}{c}\text { SMKN } 1 \\
\text { Gedangan }\end{array}$ \\
\hline 7 & $\begin{array}{l}\text { Very good and needs to be } \\
\text { done }\end{array}$ & Training needs to be held & 22 years & Female & $\begin{array}{c}\text { SMK Nusa } \\
\text { Poncokusumo }\end{array}$ \\
\hline 8 & $\begin{array}{l}\text { Difficult to pick the basic } \\
\text { competencies to combine with } \\
\text { the learning }\end{array}$ & $\begin{array}{l}\text { Cannot be forced especially the } \\
\text { private school }\end{array}$ & 25 years & Male & $\begin{array}{l}\text { SMK Dharma } \\
\text { Wanita } \\
\text { Kromengan }\end{array}$ \\
\hline 9 & $\begin{array}{l}\text { It can train students to be } \\
\text { creative, cooperative, and can } \\
\text { be applied in real-life so that } \\
\text { learning mathematics is } \\
\text { interesting }\end{array}$ & $\begin{array}{l}\text { If there are supporting items from } \\
\text { the government, especially the } \\
\text { reference to mathematics books that } \\
\text { integrated with learning of STEAM, it } \\
\text { will be effective }\end{array}$ & 24 years & Female & $\begin{array}{l}\text { SMK NU Sunan } \\
\text { Giri }\end{array}$ \\
\hline 10 & $\begin{array}{l}\text { Agree, but there are many } \\
\text { obstacles in practice }\end{array}$ & $\begin{array}{l}\text { Not to be applied in max, because of } \\
\text { the limitations of the teacher, and } \\
\text { have not received training STEAM }\end{array}$ & 24 years & Male & $\begin{array}{l}\text { SMKN } 1 \\
\text { Singosari }\end{array}$ \\
\hline 11 & $\begin{array}{l}\text { Very nice once but require a lot } \\
\text { of time. While teachers are } \\
\text { required to complete a lot of } \\
\text { basic competencies }\end{array}$ & Very well & 26 years & Male & $\begin{array}{l}\text { SMK } 10 \\
\text { November } \\
\text { Bululawang }\end{array}$ \\
\hline 12 & $\begin{array}{l}\text { Need to study a more } \\
\text { comprehensive, so the } \\
\text { precondition start/competency } \\
\text { beginning that must be held by } \\
\text { teachers in learning STEAM }\end{array}$ & $\begin{array}{l}\text { The application is quite intensive, it is } \\
\text { still limited to Revitalization } \\
\text { Vocational High School. While for } \\
\text { other schools not yet effective } \\
\text { /intensive. In fact, some vocational } \\
\text { teachers do not know at all. }\end{array}$ & 26 years & Male & $\begin{array}{l}\text { SMK Muh. } 1 \\
\text { Kepanjen/ } \\
\text { SMKN } 1 \\
\text { Wonosari }\end{array}$ \\
\hline
\end{tabular}




\begin{tabular}{|c|c|c|c|c|c|}
\hline 13 & $\begin{array}{l}\text { The integration of science, } \\
\text { technology, engineering, art, } \\
\text { mathematics needs basic } \\
\text { competencies analysis from its } \\
\text { supporting subjects, and not all } \\
\text { basic competencies can be } \\
\text { forced to collaborate }\end{array}$ & Still difficult to apply & 29 years & Female & SMKN 1 Turen \\
\hline 14 & $\begin{array}{l}\text { Good, because in vocational } \\
\text { technology was supposed to } \\
\text { learning STEAM need to be } \\
\text { applied to the chosen basic } \\
\text { competencies }\end{array}$ & $\begin{array}{l}\text { Because we still have not understood } \\
\text { very well about STEAM then to } \\
\text { implementation are still not maximal }\end{array}$ & 30 years & Female & $\begin{array}{l}\text { SMKN } 1 \\
\text { Singosari }\end{array}$ \\
\hline
\end{tabular}

Table 1 presents teachers' perceptions of the concept of STEAM convergence and the level of applying STEAM in the classroom. Table 1 at the question of Number 1 showed that teachers have a positive view of the convergence of science, technology, engineering, art, and mathematics in STEAM learning. Some teachers think that STEAM could enhance students' creativity in critical thinking, cooperation, and could be applied in real-life so that mathematics learning became interesting. The question also guided the teacher to give perceptions of convergence of various subjects in STEAM. The teachers considered that the integration of various aspects in STEAM was great and suitable for applying in the classroom. The teachers also thought that STEAM learning was indeed suitable to be applied in Vocational High Schools, but the implementation must pay attention to the Basic Competencies. This question also opens the teacher's opinion about the factors that could influence the application of STEAM in the classroom. One of the factors was the insufficiency of the time or duration used in delivering the material. Furthermore, teachers' perceptions of the application of STEAM after receiving support from the government were not optimal. This appeared in answer to Number 2, which is 7 out of 14 teachers stated that STEAM learning had not been optimally implemented because of the teacher's competency limitations. So, the teachers need to train about learning. This expression also meant that there were still many mathematics teachers in Vocational High School who had not yet participated in a training organized by the government. In addition, 4 out of 14 teachers stated that STEAM learning must be implemented. 3 out of 14 teachers stated that STEAM learning can be effective if the government provided references or supporting books.

Tabel 2. Teachers' Perceptions of Math-Focused STEAM learning

\begin{tabular}{|c|c|c|c|c|c|}
\hline \multirow[t]{2}{*}{ Subject } & $\begin{array}{l}\text { What are the easy } \\
\text { subjects to be } \\
\text { combined with } \\
\text { mathematics to } \\
\text { apply Math- } \\
\text { Focused STEAM } \\
\text { learning? }\end{array}$ & $\begin{array}{l}\text { What is your view } \\
\text { of mathematical } \\
\text { material that is } \\
\text { suitable to be } \\
\text { taught with STEAM } \\
\text { learning? }\end{array}$ & $\begin{array}{l}\text { How to use the } \\
\text { appropriate } \\
\text { mathematical } \\
\text { material with } \\
\text { STEAM learning? }\end{array}$ & $\begin{array}{l}\text { How to teach } \\
\text { Mathematics with } \\
\text { STEAM learning? }\end{array}$ & $\begin{array}{l}\text { If your plan is } \\
\text { successful, will you } \\
\text { re-apply the method } \\
\text { of teaching } \\
\text { mathematics with } \\
\text { STEAM learning in the } \\
\text { future? }\end{array}$ \\
\hline & $\begin{array}{c}\text { Answer of Question } \\
\text { (Number } 3 \text { ) }\end{array}$ & $\begin{array}{c}\text { Answer of Question } \\
\text { (Number } 4)\end{array}$ & $\begin{array}{c}\text { Answer of Question } \\
\text { (Number } 5 \text { ) }\end{array}$ & $\begin{array}{l}\text { Answer of } \\
\text { Question } \\
\text { (Number 6) }\end{array}$ & $\begin{array}{l}\text { Answer of Question } \\
\text { (Number 7) }\end{array}$ \\
\hline
\end{tabular}


Experienced Teachers' Perceptions: Math-Focused STEAM Learning || $\begin{aligned} & \text { Dewi Rosikhoh, Liny Mardhiyatirrahmah, Abdussakir, } \\ & \text { Ahmad Abtokhi, Imam Rofiki }\end{aligned}$

\begin{tabular}{|c|c|c|c|c|c|}
\hline 1 & Production & $\begin{array}{l}\text { Very little material } \\
\text { in mathematics that } \\
\text { fit with STEAM }\end{array}$ & $\begin{array}{l}\text { Learning in the } \\
\text { outside classroom }\end{array}$ & $\begin{array}{l}\text { By learning from } \\
\text { the experience in } \\
\text { outside school }\end{array}$ & Maybe \\
\hline 2 & $\begin{array}{l}\text { Science and } \\
\text { Production }\end{array}$ & $\begin{array}{l}\text { Linear Programme } \\
\text { and trigonometry }\end{array}$ & $\begin{array}{l}\text { With the practice of } \\
\text { making variables in } \\
\text { linear program } \\
\text { material }\end{array}$ & $\begin{array}{l}\text { Finding the } \\
\text { objective function }\end{array}$ & $\begin{array}{l}\text { I will carry out the } \\
\text { plan }\end{array}$ \\
\hline 3 & & $\begin{array}{l}\text { Mathematics as the } \\
\text { main focus in } \\
\text { learning STEAM is } \\
\text { difficult, but } \\
\text { mathematics can } \\
\text { help other subjects }\end{array}$ & $\begin{array}{l}\text { Need to choose the } \\
\text { material because } \\
\text { not all material can } \\
\text { be taught with } \\
\text { STEAM learning }\end{array}$ & $\begin{array}{l}\text { By way of learning } \\
\text { while playing by } \\
\text { using the tool aids }\end{array}$ & $\begin{array}{l}\text { If it works, it needs to } \\
\text { be repeated again }\end{array}$ \\
\hline 4 & Production & $\begin{array}{l}\text { It is more clearly } \\
\text { accepted by } \\
\text { students because it } \\
\text { produces tangible } \\
\text { products }\end{array}$ & $\begin{array}{l}\text { Need to discuss } \\
\text { with } \\
\text { appropriate teacher } \\
\text { of other subjects }\end{array}$ & Not practice yet & Insha Allah \\
\hline 5 & $\begin{array}{l}\text { Physics and } \\
\text { Production }\end{array}$ & $\begin{array}{l}\text { A linear program } \\
\text { that can be applied } \\
\text { to learning that can } \\
\text { produce products. } \\
\text { For example cake } \\
\text { (comparison of } \\
\text { ingredients) }\end{array}$ & $\begin{array}{l}\text { Supposition flour = } \\
\mathrm{x} \text {, butter }=\mathrm{y}, \\
\text { applied to the linear } \\
\text { inequality of two } \\
\text { variables }\end{array}$ & $\begin{array}{l}\text { Look for objective } \\
\text { functions to find } \\
\text { maximum and } \\
\text { minimum profits }\end{array}$ & $\begin{array}{l}\text { Insha Allah, I will } \\
\text { implement/apply } \\
\text { again }\end{array}$ \\
\hline 6 & $\begin{array}{l}\text { Automotive, } \\
\text { accounting, physics, } \\
\text { chemistry, } \\
\text { mathematics }\end{array}$ & $\begin{array}{l}\text { The materials which } \\
\text { become the basis } \\
\text { for other subjects } \\
\text { of basic } \\
\text { competency }\end{array}$ & $\begin{array}{lr}\text { Synergies } & \text { with } \\
\text { other } & \text { subjects } \\
\text { teachers } & \end{array}$ & $\begin{array}{l}\text { With the scientific } \\
\text { approach that } \\
\text { already exist } \\
\text { collaborated on a } \\
\text { method of the } \\
\text { invention } \\
\text { (inquiry) guided }\end{array}$ & Insha Allah \\
\hline 7 & $\begin{array}{l}\text { Yes, very much } \\
\text { needed }\end{array}$ & $\begin{array}{l}\text { Matches with the } \\
\text { development of } \\
\text { technology when it }\end{array}$ & $\begin{array}{l}\text { By way of making } \\
\text { video learning }\end{array}$ & $\begin{array}{l}\text { With direct } \\
\text { practice according } \\
\text { to each } \\
\text { department }\end{array}$ & $\begin{array}{l}\text { Must because it is } \\
\text { good }\end{array}$ \\
\hline 8 & $\begin{array}{l}\text { Mathematics and } \\
\text { physics }\end{array}$ & $\begin{array}{l}\text { Two-variable linear } \\
\text { equation }\end{array}$ & Analyze first & Analyze first & Insha Allah \\
\hline 9 & $\begin{array}{l}\text { Physics \& } \\
\text { production }\end{array}$ & $\begin{array}{l}\text { Linear Programme } \\
\text { and trigonometry }\end{array}$ & $\begin{array}{l}\text { By making variables } \\
\text { in linear program } \\
\text { material }\end{array}$ & $\begin{array}{l}\text { Finding the } \\
\text { objective function }\end{array}$ & $\begin{array}{l}\text { Insha Allah, the plan } \\
\text { will be implemented }\end{array}$ \\
\hline 10 & $\begin{array}{l}\text { Physics and } \\
\text { vocation }\end{array}$ & $\begin{array}{l}\text { Not all material can } \\
\text { be taught with } \\
\text { STEAM learning }\end{array}$ & $\begin{array}{l}\text { Choose material } \\
\text { that can be } \\
\text { collaborated }\end{array}$ & $\begin{array}{l}\text { Focus on students } \\
\text { and teachers as } \\
\text { facilitators }\end{array}$ & $\begin{array}{l}\text { Yes, if the student } \\
\text { character is good }\end{array}$ \\
\hline 11 & $\begin{array}{l}\text { Physics, chemistry, } \\
\text { biology, etc. }\end{array}$ & $\begin{array}{l}\text { Material that can } \\
\text { produce products }\end{array}$ & $\begin{array}{l}\text { Need to discuss } \\
\text { with an appropriate } \\
\text { teacher of other } \\
\text { subjects }\end{array}$ & $\begin{array}{l}\text { Focus on students } \\
\text { and teachers as } \\
\text { facilitators }\end{array}$ & $\begin{array}{l}\text { Yes, but we need care } \\
\text { about students }\end{array}$ \\
\hline 12 & $\begin{array}{l}\text { Physics, civil } \\
\text { engineering, } \\
\text { accounting, tourism }\end{array}$ & $\begin{array}{l}\text { Difficult to } \\
\text { chose the } \\
\text { material that is } \\
\text { suitable for } \\
\text { applying }\end{array}$ & $\begin{array}{l}\text { Mathematics } \\
\text { MGMP discussion } \\
\text { to choose basic } \\
\text { competency that } \\
\text { can be taught with }\end{array}$ & $\begin{array}{l}\text { basic competency } \\
\text { selection, } \\
\text { program } \\
\text { preparation, } \\
\text { implementation, }\end{array}$ & Yes \\
\hline
\end{tabular}




\begin{tabular}{|c|c|c|c|c|c|}
\hline & & $\begin{array}{l}\text { STEAM in the } \\
\text { classroom } \\
\text { - Not all basic } \\
\text { competencies } \\
\text { of mathematics } \\
\text { can be held } \\
\text { STEAM learning }\end{array}$ & $\begin{array}{l}\text { STEAM learning. } \\
\text { Mathematics } \\
\text { MGMP auditions } \\
\text { with MGMK majors } \\
\text { for synchronization. }\end{array}$ & $\begin{array}{l}\text { evaluation, } \\
\text { improvement }\end{array}$ & \\
\hline 13 & $\begin{array}{l}\text { In basically } \\
\text { mathematics can be } \\
\text { combined with } \\
\text { other subjects, but } \\
\text { basic competencies } \\
\text { were used only } \\
\text { partially small } \\
\text { course }\end{array}$ & $\begin{array}{l}\text { Mathematics as the } \\
\text { main focus in } \\
\text { learning STEAM is } \\
\text { difficult, but } \\
\text { mathematics can } \\
\text { help others subjects }\end{array}$ & $\begin{array}{l}\text { Need to discuss } \\
\text { with an appropriate } \\
\text { teacher of other } \\
\text { subjects }\end{array}$ & $\begin{array}{l}\text { Need to discuss } \\
\text { with an } \\
\text { appropriate } \\
\text { teacher of other } \\
\text { subjects }\end{array}$ & $\begin{array}{l}\text { Yes, I apply } \\
\text { mathematics with } \\
\text { STEAM learning and } \\
\begin{array}{ll}\text { collaborate with } \\
\text { natural and } \\
\text { productive subjects }\end{array}\end{array}$ \\
\hline 14 & $\begin{array}{l}\text { Material/basic } \\
\text { competencies that } \\
\text { if we can } \\
\text { collaborate with } \\
\text { other learning } \\
\text { because in the core } \\
\text { subjects it is } \\
\text { possible for others }\end{array}$ & $\begin{array}{l}\text { Yes, we adjust to } \\
\text { produce material } \\
\text { that can be } \\
\text { calculated using } \\
\text { mathematical } \\
\text { material that } \\
\text { supports }\end{array}$ & $\begin{array}{l}\text { Teachers } \\
\text { communicate with } \\
\text { other instructors } \\
\text { earning matter } \\
\text { what that if we } \\
\text { could use STEAM }\end{array}$ & $\begin{array}{l}\text { With the concept } \\
\text { of mathematics } \\
\text { which supports } \\
\text { the teaching/ } \\
\text { calculation } \\
\text { productive }\end{array}$ & $\begin{array}{l}\text { If learning STEAM can } \\
\text { be managed so it } \\
\text { automatically yes we } \\
\text { use to note is the } \\
\text { method that has been } \\
\text { proven to result } \\
\text { indeed exist }\end{array}$ \\
\hline
\end{tabular}

Table 2 presented the teacher's perception of Math-Focused STEAM learning. The answer to Number 3 in Questionnaire stated the teacher's perception of subjects that are easily combined with mathematics in STEAM learning practices. Most teachers state that subjects that are easily integrated with mathematics in STEAM learning are production subjects. This happens because most production subjects were based on technology, engineering, and art, so that the teacher holds that mathematics was easily combined with these subjects. In addition, the teacher also believed that mathematics was easily combined with science subjects namely physics, biology, and chemistry. However, the most chosen science subject was physics because the subjects helped to produce a project. The answer to Number 4 in Questionnaire appeared that 4 out of 14 teachers stated that examples of suitable mathematical material taught by STEAM learning are linear equations of two variables, linear programming, and trigonometry. It also stated that 6 out of 14 teachers said which mathematics as a main focus in STEAM learning is rather difficult to apply so that only a few materials were suitable for STEAM learning. There were 4 out of 14 teachers stated that suitable mathematics material taught with STEAM was material that was a basic material for other subjects. The statement indicated that mathematics was used as supporting material and not as a material focus in STEAM learning. Questionnaires 5 and 6 implied the same thing, namely the teacher's perception of how to use and teach mathematics with STEAM learning. According to the teacher, it was necessary to discuss with other subject teachers integrated into STEAM to synchronize the appropriate basic competencies. Whereas for the answer to Number 7 in Questionnaire, it stated the teacher's perception about the application of STEAM in the future. Almost all teachers were optimists to apply STEAM learning. 
The results showed that teacher perceptions of STEAM convergence were positive. These results were consistent with the results of the study that were done by Kang (2019), Kim et al. (2019), and Park et al. (2016). The teacher thought that STEAM could enhance students' creativity in critical thinking, cooperation, and could be applied in real-life so that studying mathematics became interesting. However, teachers assumed that the implementation of STEAM was not optimal despite support from the government. The most obstacles that were related to the time or duration of the application of STEAM Mathematics learning in the classroom because of the projecttask. In addition, another mentioned factor was the lack of teacher competence in teaching STEAM because there were teachers who didn't get training and no supporting references for STEAM learning. These constraints were also in line with the findings of previous researchers but in different terms. Previous research mentioned these constraints with lack of educational resources, and a lack of administration (Kim et al., 2019; Park et al., 2016). The finding of constraints from Park et al. (2016) was a matter of time, workload, administrative and financial support. While the findings of constraints from Kim et al. (2019) were time, materials, and educational resources. Based on this study, before implementing STEAM Mathematics based learning in the classroom, teachers needed to get even training on this subject and be able to work in synergy with other subject teachers. The mathematics teacher must also be able to organize the available time so that it is sufficient to be used in this STEAM-based learning.

The other result was the teacher's view on subjects that were easily combined with mathematics are productive subjects. These productive subjects include technology, engineering, art, and science subjects including physics, chemistry, biology. All of these subjects were still integrated into STEAM. This finding was new because previous research examines elementary school level where the learning was still thematic. This result of the research was different since STEAM learning focusing on mathematics in vocational high schools. This happens because subjects in vocational schools have focused on one subject for one discipline. It became a challenge for teachers because teachers at this level usually learned to focus only on the subjects taught. In addition, the researchers also found the teacher's view that only a little mathematics material could be implemented in STEAM when mathematics was the focus of learning. The teacher added to the opinion that mathematics was more suitable as supporting material rather than became a focus on STEAM learning. This was certainly supported by the theory which stated that mathematics is the queen of science (Yadav, 2017). Mathematics as a basic science that must be learned in learning other disciplines, so that if mathematics became the focus of the material it would be very difficult to develop. 
Furthermore, to implement math-focused STEAM learning, teachers reveal that the need to coordinate or discuss with other teachers about the other subjects because STEAM learning was the convergence of various aspects of science, technology, engineering, art, and mathematics. The application needed to be discussed deeply so that it remains by the basic competencies that had been regulated by the government and able to be in line with other subjects. If all lessons were able to coordinate with each other, then this can have an impact on student assessment related to mathematics. Although the teacher conveyed the obstacles in the implementation, the teacher remained optimistic to implement STEAM learning in the future.

\section{第 Conclusion}

To sum up, teachers have a positive view of the convergence of STEAM. Even so, teachers considered that there were obstacles in the implementation of STEAM learning like there are the teachers who had not participated in the training of teachers' competencies in Math-Focused STEAM learning and no books that were available as a reference in STEAM learning. STEAM learning with mathematics as the main focus is rather difficult to apply because the teacher thinks that only a little of mathematics material could be implemented in STEAM learning. According to the teacher, mathematics is more suitable as supporting material in STEAM learning rather than being the focus.

\section{Bibliography}

Bhagat, K. K., \& Chang, C. Y. (2015). Incorporating GeoGebra into geometry learning-A lesson from India. Eurasia Journal of Mathematics, Science and Technology Education, 11(1), 77-86.

Boy, G. A. (2013). From STEM to STEAM: Toward a human-centred education, creativity \& learning thinking. In Proceedings of the 31st European conference on cognitive ergonomics ( $\mathrm{p}$. 3). Toulouse, France: ACM Digital Library.

Gürbüz, R., \& Erdem, E. (2016). Relationship between mental computation and mathematical reasoning. Cogent Education, 3(1), 1212683.

Henriksen, D. (2014). Full STEAM ahead: Creativity in excellent STEM teaching practices. The STEAM journal, 1(2), 1-7.

Henriksen, D. (2017). Creating STEAM with design thinking: Beyond STEM and arts integration. The STEAM Journal, 3(1), 1-11.

Herro, D., \& Quigley, C. (2016). Innovating with STEAM in middle school classrooms: Remixing education. On the Horizon, 24(3), 190-204.

Herro, D., \& Quigley, C. (2017). Exploring teachers' perceptions of STEAM teaching through professional development: Implications for teacher educators. Professional Development in Education, 43(3), 416-438.

Herro, D., Quigley, C., Andrews, J., \& Delacruz, G. (2017). Co-Measure: Developing an assessment for student collaboration in STEAM activities. International journal of STEM education, 4(1), 1-12.

Jho, H., Hong, O., \& Song, J. (2016). An analysis of STEM/STEAM teacher education in Korea with a case study of two schools from a community of practice perspective. Eurasia Journal 
of Mathematics, Science and Technology Education, 12(7), 1843-1862.

Kang, N. H. (2019). A review of the effect of integrated STEM or STEAM (science, technology, engineering, arts, and mathematics) education in South Korea. Asia-Pacific Science Education, 5(1), 6.

Keiler, L. S. (2018). Teachers' roles and identities in student-centered classrooms. International journal of STEM education, 5(1), 34.

Kim, J. Y., \& Lim, K. Y. (2019). Promoting learning in online, ill-structured problem solving: The effects of scaffolding type and metacognition level. Computers $\mathcal{E}$ Education, 138, 116-129.

Kim, M. K., Lee, J. Y., Yang, H., Lee, J., Jang, J. N., \& Kim, S. J. (2019). Analysis of elementary school teachers' perceptions of mathematics-focused STEAM education in Korea. EURASIA Journal of Mathematics, Science and Technology Education, 15(9), 1-13.

Kim, S. H. (2017). Science, technology, and the imaginaries of development in South Korea. Development and Society, 46(2), 341-371.

Kim, S. W., \& Lee, Y. (2018). An investigation of teachers' perception on STEAM education teachers' training program according to school level. Indian Journal of Public Health, 9(9), 256-263.

Koni, I., \& Krull, E. (2018). Differences in novice and experienced teachers' perceptions of planning activities in terms of primary instructional tasks. Teacher Development, 22(4), 464480.

NCTM. (2000). Principles and standards for school mathematics. Reston, VA: National Council of Teachers of Mathematics.

Park, H. J., Byun, S. Y., Sim, J., Han, H., \& Baek, Y. S. (2016). Teachers' perceptions and practices of STEAM education in South Korea. Eurasia Journal of Mathematics, Science and Technology Education, 12(7), 1739-1753.

Sheffield, R., Koul, R., Blackley, S., Fitriani, E., Rahmawati, Y., \& Resek, D. (2018). Transnational examination of STEM education. International Journal of Innovation in Science and Mathematics Education, 26(8), 67-80.

Tehseen, S., \& Hadi, N. U. (2015). Factors influencing teachers' performance and retention. Mediterranean Journal of Social Sciences, 6(1), 233-244.

Timperley, H. S. (2015). Continuing professional development. International Encyclopedia of the Social \& Behavioral Sciences, 4, 796-802.

Yadav, D. K. (2017). Exact definition mathematics. International Research Journal of Mathematics, Engineering and IT, 4(1), 34-42.

Yakman, G. (2008). STEAM education: An overview of creating a model of integrative education. In Pupils' Attitudes Towards Technology (PATT-19) Conference: Research on Technology, Innovation, Design \& Engineering Teaching, Salt Lake City, Utah, USA.

Yakman, G., \& Lee, H. (2012). Exploring the exemplary STEAM education in the US as a practical educational framework for Korea. Journal of the Korean Association for Science Education, 32(6), 1072-1086.

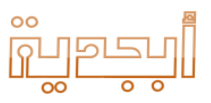

